Александра Ђурић Миловановић ${ }^{1}$

Балканолошки институт САНУ, Београд
Оригинални научни рад

UDK 323.15:2(=135.1)(497.113)

Примљено: 02.11.2020.

Ревидирана верзија: 13.11.2020.

Одобрено за штампу: 18.11.2020.

DOI: https://doi.org/10.46630/gsoc.26.2021.02

\title{
СКРИВЕНИ ИДЕНТИТЕТИ РУМУНСКИХ НЕОПРОТЕСТАНТСКИХ ЗАЈЕДНИЦА У ВОЈВОДИНИ
}

\begin{abstract}
Ancтракт: Мањинске заједнице у Србији се врло често посматрају из угла једног типа мањинског идентитета - етничког. Када је реч о религијском идентитету мањинских заједница, још увек је недовољан број студија и истраживања посвећених сложеном односу између етничког и религијског идентитета. На основу вишегодишњих теренских истраживања Румуна који припадају неопротестантским заједницама у Војводини, у овом раду анализирам етнички и религијски идентитет мањинских заједница кроз призму концепта двоструких мањина. Полазећи од хипотезе да границе етничког и религијског идентитета нису унапред дефинисане и статичне, анализирам наративе прикупљене теренским истраживањем у четири неопротестантске заједнице. У раду, пример Румуна неопротестаната показује каква је улога конверзије (обраћења) у етничким и религијским мањинским заједницама, као и колико религијски идентитет постаје хомогенизујући чинилац у наднационалним верским заједницама.
\end{abstract}

Кључне речи: мањине у Србији, Румуни у Војводини, религијски идентитет, двоструке мањине, неопротестанти

\section{Увод}

Предмет овог рада је румунска заједница у Војводини, односно Румуни који припадају различитим мањинским неопротестантским верским заједницама и које дефинишем као двоструке мањине. Религијски идентитет етничких мањина у Војводини, представља веома слојевиту и комплексну тему, иако се стиче утисак да су етничке мањине религијски врло хомогене, односно моноконфесионалне. Тако су Румуни виђени као православци, Словаци као лутерани, Мађари као католици или калвинисти, Русини као грко-католици (унијати) и слично. Међутим, религијски идентитет у Војводини је током векова представљао динамичну и понекад променљиву форму, а томе су у великој мери допринеле протестантске заједнице. Како наводи историчар Бојан Алексов, појава нових протестантских заједница довела је до стварања религијски хе-

\footnotetext{
${ }^{1}$ aleksandra.djuric@bi.sanu.ac.rs
} 
терогене слике друштва у временима која су обележиле драматичне промене „на простору на којем су се сусретале, преплитале и надграђивале различите културне, друштвене, политичке и верске традиције“ (Алексов 2010, 12).

Неопротестантизам се везује за период када се почетком и средином 19. века у Европи и Сједињеним Америчким Државама оснивају верске заједнице, изворно настале из радикалних огранака реформације, као што су назарени, адвентисти седмог дана, баптисти, пентекосталци, методисти. Њихово ширење на постору источне Европе везује се за средину 19. и почетак 20. века (Parushev \& Pilli, 2004, 156). Стога термин неопротестантизам укључује оне верске заједнице које имају одређене заједничке карактеристике, а које се са друге стране разликују од традиционалних протестантских заједница из којих су изворно настали. То се пре свега односи на одбацивање ритуала у богослужењу, наглашавање супремације Библије, крштење одраслих верника, мисионарске активности (Рор 2009, 139). Према Сабрини Петри Рамет поједине неопротестантске заједнице изворно настају у источно европским земљама (у Пољској, Чешкој, Словачкој, Мађарској), што није био случај са земљама Балкана, где се неопротестантизам ширио путем мисионара из централне и западне Европе (Ramet 1992: 8). Иако су неопротестантске заједнице присутне на простору данашње Војводине већ више од једног века, стиче се утисак да су у научним истраживањима недовољно истражене, а у јавном дискурсу врло често непознате или се перципирају у негативном дискурсу као секте. Стигма која прати припаднике мањинских верских заједница у тесној је вези и са њиховим статусом одређеним на основу Закона о верским заједницама из 2006. године. Према Закону, мале верске заједнице спадају у нетрадиционалне групе и дефинисане као конфесионалне заједнице 2 .

Истраживања мањинских верских заједница на простору Војводине започела сам 2008. године у оквиру пројеката Балканолошког института САНУ и она су трајала до 2012. године 3 . Реч је о етнографским истраживањима квалитативног типа која су највише обухватала Румуне који припадају неопротестантским заједницама: назарени, баптисти, адвентисти седмог дана и пентекосталци (Ђурић Миловановић 2015). Полазећи од хипотезе да границе етничког и религијског идентитета нису унапред дефинисане и статичне, овај рад има за циљ да на примеру Румуна неопротестаната укаже каква је улога конверзије (обраћења) у етничким и религијским мањинским заједницама, која је улога мобилности проповедника и верника у ширењу верских учења, као и колико религијски идентитет постаје хомогенизујући чинилац у тзв. наднационалним верским заједницама.

\footnotetext{
${ }^{2}$ Према поменутом закону, у традиционалне верске заједнице убрајају се Српска православна црква, Римокатоличка црква, Словачко-евангеличка црква а. в., Реформатска хришћанска црква, Евангеличка хришћанска црква, Јеврејска и Исламска заједница. Конфесионалне заједнице су оне заједнице уписане у Регистар цркава и верских заједница, на основу прописаног начина регистровања и има их 16, међу којима су већином различите неопротестантске заједнице, иако има и оних које су одбиле да се региструју по новом закону. О алтернативним и новим религијама у Закону о верским заједницама, више у студији Синани 2010, 121-132.

${ }^{3}$ Резултати ових истраживања објављени су у монографији „Двоструке мањине у Србији. О посебностима у религији и етницитету Румуна у Војводини“, 2015.
} 


\section{Румуни у Војводини - савремено стање}

Према подацима са последњег пописа становништва из 2011. године, 29.332 се изјаснило Румунима. ${ }^{4}$ Највише Румуна има на простору Војводине 25.410. Уколико упоредимо резултате претходних пописа из 1991. и 2001. године, можемо видети да се број Румуна смањио са 38.000 на 30.419. На опадање броја становника утицале су радне миграције, које су према демографским истраживањима посебно присутне код припадника румунске заједнице (Ромелић, Нађ, Бјељац 2010: 5). Румуни у Војводини живе у десет општина, међу којима је највећи број у општини Алибунар, Вршац и Панчево. Румунској заједници у Војводини основна мањинска права гарантована су Уставом Републике Србије и законима, стога Румуни имају право на службену употребу матерњег језика и писма, очување и развој културе, право на информисање на матерњем језику.

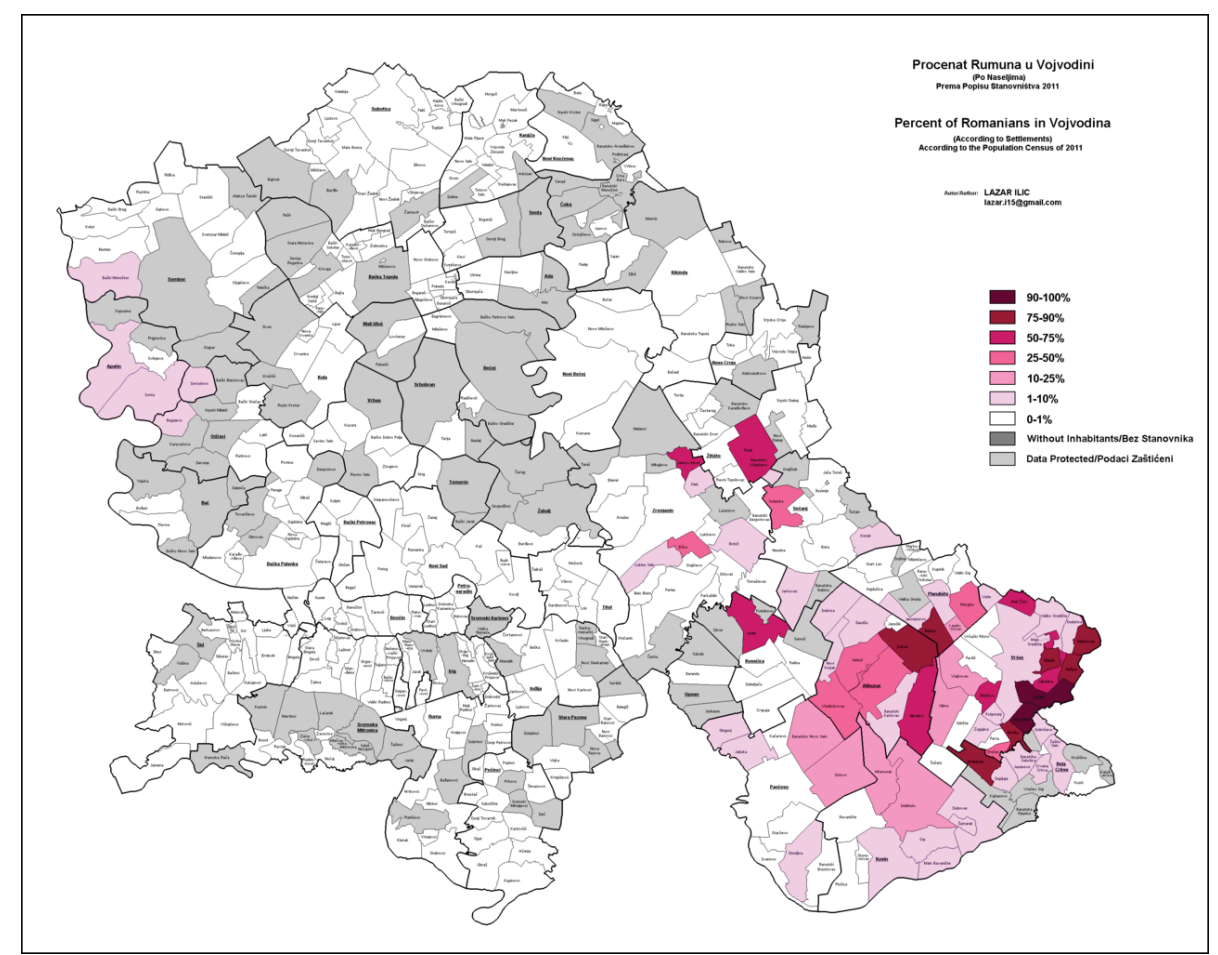

Слика 1: Проценат Румуна у Војводини (по насељима) према Попису становништва из 2011. године

Румуни су се највише исељавали у Северну Америку и земље западне Европе - Швајцарску, Аустрију, Немачку, Шведску и Италију. Таласи миграција током 20. века у великој мери су утицали на савремену демографску слику.

\footnotetext{
${ }^{4}$ https://pod2.stat.gov.rs/ObjavljenePublikacije/Popis2011/Nacionalna\%20pripadnost-Ethnicity.pdf, приступљено 01.09.2020.
} 
Према члану 2 Закона о заштити права и слобода националних мањина, „Национална мањина у смислу овог закона је свака група држављана Републике Србије која је по бројности довољно репрезентативна, иако представља мањину на територији Републике Србије, припада некој од група становништва које су у дуготрајној и чврстој вези са територијом Републике Србије и поседује обележја као што су језик, култура, национална или етничка припадност, порекло или вероисповест, по којима се разликује од већине становништва, и чији се припадници одликују бригом да заједно одржавају свој заједнички идентитет, укључујући културу, традицију, језик или религију5.“ Иако су Румуни у Војводини у највећем броју православци и Румунска православна црква спада у најстарије конфесије, међу Румунима има и Гркокатолика и неопротестаната. Румунска грчко-католичка црква (унијати) основана је 1864, а крајем 19. и почетком 20. века међу Румунима се јављају и различите неопротестантске верске заједнице: назарени, адвентисти, баптисти, пентекосталци.

\section{Религијски идентитет и транснационалне везе међу неопротестантским заједницама}

О хетерогености религијског идентитета Румуна у Војводини постојали су оскудни подаци у истраживањима која је осамдесетих година обавила етнолог Мирјана Малуцков (1985). Малуцков у монографији „Румуни у Банату: етнолошка истраживања“, наводи постојање унијатских (грко-католичких) заједница у Марковцу и Јанковом Мосту. Поред тога, Малуцков истиче „У другој половини 20. века приметни су утицаји разних секти, међу којима су назарени (појављују се још крајем 19. века) и адвентисти као најбројнији (Малуцков 1985: 15). Малуцков овај податак цитира из пионирског, али до сада необјављеног, истраживања мањинских верских заједница на простору Баната. Истраживање малих верских заједница на територији општине Панчево обавила је група етнолога Никола Павковић, Душан Бандић и Радомир Ракић 1978. године (Павковић, Бандић и Ракић 1978). Доступни извори и литература о религији Румуна у Војводини садржи највише података о Румунима православцима, односно о елементима традицијске културе и обичајима који се везују за православље. Међутим, веома богат и динамичан верски живот ове етничке заједнице, нарочито током међуратног периода, указује да је сагледавање етничких мањина кроз призму доминантне конфесије ограничавајући и да представља само један од више типова религијског идентитета.

Постојање веома бројне румунске назаренске заједнице у селу Локве у Банату, отворило је и различита питања када је реч о заступљености етничких мањина у малим/мањинским верским заједницама, које и данас прати висок степен стигматизације и маргинализације. О степену стигматизације и затво-

\footnotetext{
${ }^{5} \mathrm{https}$ //www.paragraf.rs/propisi/zakon_o_zastiti_prava_i_sloboda_nacionalnih_manjina.html, приступљено 01.09.2020
} 
рености припадника малих верских заједница говори и чињеница да је процес теренског истраживања трајао више година, као и да је „улазак“ у заједницу којој истраживач не припада у појединим случајевима до самог краја истраживања био онемогућен 6 . Процес истраживања у малим верским заједницама је дуготрајан и захтева одређени степен познавања специфичности сваке појединачне заједнице. Будући да је реч о малобројним заједницама, које веома ретко посећују аутсајдери, однос истраживача и испитаника носи и додатна оптерећења, док је једно од кључних етичких питања „откривање“ чланова малих верских заједница.

Сазнања о мањинским верским заједницама у јавном дискурсу врло често се креирају кроз идентификацију истих са термином секта. Са друге стране страх од одбацивања и повремени напади на припаднике малих верских заједница и њихових проповедника (пастора), најбоље се огледа у њиховој скривености, а врло често и о скривености њихових молитвених домова. Најчешће се места окупљања, односно молитвени домови не разликују од обичних кућа, осим што су током последњих година заједнице почеле да стављају натписе. Изолацијом од ширег друштвеног окружења, неопротестантске заједнице „верском гетоизацијом“ покушавају да заштите свој религијски идентитет.

Иако су назаренске заједнице основане средином 19. века међу Немцима и Мађарима протестантима, њима су се у већем броју врло брзо прикључили Срби и Румуни. Доласком једне новије протестантске заједнице, која своје учење темељи на анабаптизму и немачком пијетизму, наглашавајући да је ново рођење могуће покајањем и крштењем одраслих, назарени ће отворити пут оснивању сличних заједница које ће изменити религијску структуру јужних делова Угарске (Алексов 2006). Пацифизам је био још једна од кључних карактеристика коју су назарени сматрали својим идентитетским обележјем. На њихово ширење са простора Швајцарске ка Аустро-Угарској, највише су утицали Мађари калвинисти, којима су учења назарена у одређеној мери била блиска. Употреба народног језика током богослужења, као и певање из песмарице Харфа Сиона, коју је са немачког на српски превео Јован Јовановић Змај, утицала је на многе Србе, али и Румуне да напусте православље и постану назарени ${ }^{7}$. О ширењу назаренства постојали су бројни чланци, посебно у црквеној штампи који су говорили о наглом порасту броја верника, као и о појединим карактеристикама ове заједнице која се православцима чинила страном и неуобичајеном. На основу доступних архивских извора, односно писама румунских православних свештеника може се закључити да су назарени међу Румунима били

\footnotetext{
${ }^{6}$ Студија посвећена одбијању истраживача и проблемима уласка у затворене верске заједнице више у студији: Gilliat-Ray 2005, 7-33. О затвореном терену, као и различитим ризицима током теренског истраживања видети у Сикимић 2008, 81-93.

${ }^{7}$ Јован Јовановић Змај је са Ђорђем Рајковићем превео са немачког оригинала српски језик Харфу Сиона 1878, што је имало велики утицај на ширење назаренства међу Србима. О односу Змаја и назарена, више у студији: Алексов 2011.
} 
присутни још 1872. године ${ }^{8}$. Након назарена, оснивају се и прве адвентистичке заједнице у Банату 1910. године, где су се окупљали по кућама, а крштења обављали на рекама (Бјелајац 2010: 104).

Будући да у овом прилогу не разматрам историјски контекст развоја неопротестантизма, истакла бих да је положај у којем су се неопротестантске заједнице налазиле у различитим историјско-друштвеним околностима током 20. века, у великој мери утицао на њихов положај данас ${ }^{9}$. Ширење других неопротестантских заједница као што су адвентисти, баптисти и пентекосталци, последица је мисионарења појединих проповедника из Румуније, који су уз дистрибуцију публикација на румунском језику, крштавали вернике у насељима Баната. Важно је поменути да је утицај румунске неопротестантске дијаспоре на оснаживање и развој заједница имао значајну улогу. Наиме, везе које су постојале са верницима који су одлазили у Северну Америку или земље западне Европе, имале су кључну улогу након Другог светског рата. Када се положај неопротестантских заједница драстично погоршао и када су због пацифизма и одбијања да служе војску и полажу заклетву, многи назарени, али и адвентисти били осуђивани на строге затворске казне, помоћ дијаспоре је била кључна за опстанак заједница и њихових породица (Ђурић Миловановић 2017, 447-457). Адвентисти су због одбијања рада суботом, као и због одбијања да њихова деца похађају школу суботом, такође били осуђивани на затворске казне. Због неповољног положаја у којем су се нашли, као и због праксе поновљених казни затвора, велики број неопротестаната одлази у иностранство. На њихову емиграцију утицали су бројни фактори, али и чињеница да су у земљама у које су одлазили већ постојале заједнице којима би се они прикључили, те су заједнице биле својеврстан канал за емиграцију. Поред тога, снажан принцип заједништва и односа међу верницима као браћи и сестрама у Христу, имали су значајну улогу у интеграцији у нову средину. И након одласка, везе и контакт са онима који су остали није се прекидао. О томе сведоче и бројна писма која су размењивали са заједницама у Банату, као и са посебним хуманитарним фондовима за помоћ породицама чији су чланови били на служењу казне затвора. Ови подаци говоре о развијеној транснационалној мрежи која је постојала међу неопротестантима, начину функционисања заједница у различитим друштвено-историјским околностима, али и откривању канала емиграције већег броја верника након Другог светског рата (Ђурић Миловановић 2017: 447-457). И данас ти верници материјално помажу изградњу нових цркава и обнову постојећих, посећују их и одржавају проповеди: Наша браћа из Америке долазе сваке године. Обновили смо цркву уз њихову помоћ. Има пуно Румуна тамо, и у Канади и у Аустралији (Н, Стража).

\footnotetext{
${ }^{8}$ Румунски православни свештеници обратили су се епископу Јоану Попасуу за „помоћ у искорењивању секте назарена која се учврстила у њиховој заједници“. Архива Протопрезвитерата у Банатском Ном Селу, писмо Павела Милитариуа и Јоана Русована протопрезбитеру Румунске православне цркве, 16. новембар 1872. године.

${ }^{9}$ Детаљнији преглед развоја протестантизма, али и неопротестантских заједница, доступан је у две монографије Бранка Бјелајца 2003, 2010. О почецима назаренства, као и разлозима ширења назарена међу Србима више у студији Бојана Алексова (2006).
} 
Према подацима прикупљеним приликом истраживања баптистичких заједница у Темишвару (јун 2009. године), током 2007. године покренут је пројекат партнерства са баптистичким црквама у Србији, у оквиру којег румунски баптистички мисионари долазе неколико пута месечно у одређене цркве у Војводини, али и на југу Србије. Проповеди пастора су на румунском језику, уз обезбеђени консекутивни превод. Такође, ово партнерство омогућава и лакшу дистрибуцију различите верске литературе на матерњем румунском језику за Румуне у Војводини. Улога коју оваква врста сарадње има, односи се пре свега на јачање недовољно развијених баптистичких заједница, посебно у руралним срединама, али и повезивање румунске дијаспоре са матичном земљом. Сличан пример наводи и етнолог Михал Павлашек ослањајући се на концепт „прекограничног национализма““ (енг. cross-border nationalism), у случају Чеха протестаната у Банату досељених из Моравске у 19. веку (Pavlásek 2013: 195207). Контакти и мрежа која и данас постоји у случају ове малобројне заједнице оснажена је улогом мисионара-учитеља који су имали улогу у Мобилност верника је данас свакако много већа него што је била некада, посебно од уласка Румуније у Европску унију и укидања визног режима. Тако су, према реакцијама саговорника на терену, политички процеси конституисања или укидања рестрикција границе за одређене држављане могли имати, као последицу, промене политичког статуса Румуније, односно уласку Румуније у Европску унију 1. јануара 2007. године, те аутоматски праћени сличним процесима „укључења”/ „искључења” у свести људи. Део разговора на терену, снимљен у априлу 2007. године у српском Банату то управо показује: Раније смо имали среће. Румуни из Румуније су долазили овде. А сада они у Румунији иду даље. Њима је дозвољено, нама није. Ситуаиија се променила. Било је добро када смо могли да идемо где хоћемо (А, Јабланка).

Након дужег периода стагнације, последњих деценија дошло је до пораста броја верника у румунским неопротестанским заједницама, што се може довести у везу са утицајима румунске дијаспоре и мисионара, затим дијаспоре који материјално помажу заједнице у Србији, као и улоге медија на матерњем (румунском) језику. Важно је поменути и улогу савремених начина мисионарских активности у ширењу неопротестантских заједница. Наима, како Дејвид Мартин наводи „у савременом свету масовних комуникација и географске мобилности мисионарство више није неопходно. Мисионари, наравно, постоје но и да не постоје евангелистичка експанзија би била скоро потпуно иста, због могућности ширења верских порука путем личних или породичних контаката. Брзина којом се крећу људи и идеје постаје све већа“ (Martin 2008: 53). Тако интернет презентације и друштвене мреже бројних неопротестантских заједница у Румунији, омогућују повезивање са заједницама у региону. На интернет презентацијама баптистичке, адвентистичке или пентекосталне цркве, верници могу слушати проповеди на румунском језику, пратити догађаје у одређеној цркви, концерте, евангелизације или предавања о различитим религијским темама. Наводећи пример тзв. „електронских цркава“ у Сједињеним Америчким Државама, Бранимир Стојковић и Мирољуб Радојковић, наглаша- 
вају значај телевизијског програма, као што је телевангелизам. Тако, телевизијску промоцију могу да плате све верске заједнице које су заинтересоване за такву врсту промоције (Стојковић, Радојковић 2004: 140). Румуни адвентисти у Србији прате телевизијски проповед локалне цркве у Вршцу, на румунском језику, али и специјализоване програме из Румуније преко сателита (рум. $T V$ Speranța) који емитују целодневни програм верске садржине. Баптистичке цркве емитују своје проповеди онлајн, али постоји и радио на румунском језику који се такође може слушати преко интернета ${ }^{10}$. Када говори о свеприсутности различитих религија на интернету, Лорн Давсон истиче да је кључна разлика између телевизије и интернета у интеракцији - на интернету људи могу писати и читати о религији, разговарати са другима о религији, виртуално учествовати у службама различитих заједница (Dawson 1999). То је посебно постало важно и актуелно питање у периоду пандемије КОВИД-19 када су многобројне заједнице проповеди емитовале онлајн. Са друге стране језички идентитет у неопротестантским заједницама је веома важан, будући да су у већини истраживаних заједница службе билингвалне, српско-румунске. Један од старешина назаренске заједнице истакао је: „Чак и ако би у заједници био само један верник мађарског, словачког или румунског порекла, служба би била на тим језицима. Свако веру и реч Божију разуме боље на свом језику“ (Н, Избиште). Певање химни, богате догматске садржине, представља заједнички елеменат свих неопротестантских заједница. Поред тога што верници кроз химне изражавају емоције према Богу, певање има и кључну улогу у јачању колективног идентитета у заједници. Следећи фрагмент разговора са назаренским верником из Страже (јужни Банат) то и показује: „Имамо песме Харфа Сиона, то је из јеванђеља. Ово читате у скуштини? Да, ово се чита широм планете земље, свако на свом језику. У Америци имају на српском, румунском и на енглеском. Био сам у Америци у скуитини“ (Н, Стража).

Језик за неопротестанте има веома важну улогу, посебно у етнички хетерогеним заједницама у којима се често инсистира на вишејезичним проповедима. Употреба матерњег језика у богослужбеној пракси, посебно када је реч о припадницима етничких мањина, оправдава се чињеницом да ће верници најбоље моћи да прате богослужење на матерњем језику. Са друге стране, број верника у баптистичкој или пентекосталној заједници много је већи захваљујући јавним евангелизацијама и прилагођености новим друштвеним токовима, у односу на конзервативније назарене. Врло често је затворен и стигматизован положај у оквиру „шире“ заједнице, условљен положајем двоструке мањине Румуна неопротестаната, али и других припадника етничких заједница на простору Војводине, који припадају некој од бројних малих верских заједница.

\footnotetext{
10 Листа хришћанских (баптистичких) радио станица доступних преко интернета може се наћи на: http://bbim.ro/category/radio-crestin-online/. Приступљено 05.09.2020.
} 


\section{Двоструке мањине у Војводини и флуидност граница идентитета}

Иако припадници етничких мањина најчешће припадају доминантној конфесији, међу њима постоје и они који чине део и у мањинским верским заједницама. Поједини аутори сматрају да је приврженост доминантној религији посебно изражена код припадника етничких мањина које живе у непосредној близини своје матичне државе. Према Роџеру Брубејкеру реч је о „тријангуларној историјској везаности“ између мањинске заједнице којој припадају, њених институција и матичне земље (Brubaker 1993: 1-21). У случају румунске мањине у Војводини, припадност Румунској православној цркви представља важан елемент колективног идентитета, али и етничког. У условима када се одређене етничке групе идентификују пре свега као конфесионалне заједнице, религија преузима улогу маркера етничког идентитета (Бонета, Бановац 2007: 169). Напуштањем доминантног модела „Румуна православца“ и приступање неопротестантским заједницама, стварају се нови модели понашања који су сада утемељени на религијским нормама одређених заједница. Како је приступање неопротестантским заједницама праћено процесом конверзије или обраћења, нови идентитет у великој мери дефинише њихове односе према „спољном свету“ и „другима“. Тако је према антропологу Воутеру Думону, религија виђена као најважнији елемент који дефинише „истост“ и „другост“, а не етнички идентитет (Dumont 2003: 379). Већина неопротестаната суштину свог обраћења види у покајању, односно у стварању личног односа са Богом и прихватању Исуса Христа као „личног спаситеља“. Саставни део процеса конверзије је покајање, без којег будући верник не може приступити заједници. Као и код традиционалних протестантских заједница, Библија и дословно тумачење Библије представља централни елемент у животу верника и често се описује као тренутак „откровења“. Неопротестантизам акценат ставља на личну одлуку појединца да приступи заједници, као и на крштењу одраслих, насупрот крштењу деце које се практикује у другим хришћанским традицијама. Тако крштењу, претходи период проучавања Библије и припреме за приступање заједници када појединац постаје пријатељ заједнице. Један од саговорника је навео: „крштење се прави када се одлучи, само примамо кроз критење и веру у Исуса. Људи дођу, ми обавестимо све и онда дођу да присуствују критењу. Тек после критена постаје члан иркве. Крштењем се грех спере. Ако неко хоће да служи Исусу Христу значи да треба да промени начин живота“" (А, Банатско Ново Село). Слично тумачење конверзије/крштења, имао је саговорник из пентекосталне цркве који наводи да са неким основним начелима заједнице у коју појединац присупа мора да буде упознат „критење је својевољно приступање, представља одрииање старог човека, рођење новог. Исус Христос је био критен. Закопавање старог човека и уздизање новог. Од тог тренутка ти пред људима потврђујеш да си Христов, односно да ти хоћеш да идеш Христовим стопама, односно да разумеш ту истину. Било би нелогично, знаш, да то радиш из формалних разлога. Мораш да знаш, да 
преиспиташ човека да ли је он свестан ита чини, коју радюу чини. Да не би човек био у заблуди. Код неких има пре крштења, одређена библијска подучавања" (П, Вршац). Док је други саговорник истакао "Како сам се ја обратио? Ја сам се обратио у ствари ја сам Свето Писмо читао. Један протестант не постаје ако ја вас убедим, него када Библија уђе у ваше руке. Човек који постане протестант сам зна да објасни Свето Писмо, не постаје сваки човек протестант. Онако како је написано, Библија мора да се да народу, да буде доступна онако како је написана, боље би било да му се уопште и не даје никакво библијско подучавање" (Б, Мали Жам).

Нови религијски идентитет постаје важнији маркер колективног идентитета у односу на етнички ${ }^{11}$. У разговору са једном саговорницом из мешовите српско-румунске назаренске заједнице, она запажа да се у назаренским скупштинама не наглашава „румунство“, које се према њеном мишљењу највише изражава употребом румунског језика. Приметно је дистанцирање од румунске традицијске културе, посебно од „обичаја који су се некад обележавали када су били православци“. Перцепција православних обичаја и традиције са елементима народне религије врло често је негативна, будући да се према неопротестантима не темељи на учењима из Библије. Интересантан пример налазим у селу Гребенац, где је једна саговорница учествовала у покладној прослави фашанки, маскирала се, певала песме „из света“, причала вицеве ${ }^{12}$. Након што је постала назаренка, такав вид понашања сматра непрохватљивим за људе који су у „вери“ наспрам оних из „света“.

Неопротестантизам као „религија личне промене“, етнички идентитет не сматра значајним за религијску праксу. Саша Недељковић истиче да је „теоријски могуће да религијски идентитет буде самосталан и да није у непосредној вези са етничком или националном припадношћу, иако је у пракси та самосталност сложена и вишезначна“" (Недељковић 2007: 256). Комплексност односа религија-етнички идентитет настаје и због преклапања православне религије и етничког идентитета, што је случај са Румунима. Уколико Румун не дели верске праксе већине у својој заједници, не обележава верске празнике на исти начин, заједница ће таквог појединца маркирати као да не припада румунском етникуму и као да „угрожава“ друштвену кохезију. Такве поделе унутар локалних заједница, утичу да се Румуни неопротестанти врло често негативно перципирају од стране Румуна, али и Срба православаца. Приликом једне од годишњих евангелизација у селу Уздин, адвентисти су изнајмили двориште тзв. румунске куће у којој се одржавају разне културно-уметничке активности. У овој локалној заједници, адвентисти немају своју заједницу, стога су евангелизације у виду јавних проповеди на одређене теме, позив широј заједници

\footnotetext{
${ }^{11}$ Неопротестанти се позвивају на новозаветни цитат апостола Павла у посланици Галатима 3:28 где се наглашава принцип једнакости пред Богом: „нема ту Јеврејина ни Грка, ни роба ни господара, нема мушког рода ни женскога. Јер сте ви сви једно у Христу Исусу“.

${ }^{12}$ О улози локалног обичаја фашанки у селу Гребенац више у Павковић и Наумовић 1996: 697708.
} 
да присуствује овом догађају. Међутим, натпис који је освануо на месту где се одржавају евангелизације, према речима саговорника, наводе да су адвентисти „секташи“. Међутим, евангелизације су саставни део организоване мисијске акције у оквиру адвентистичке, баптистичке или пентекосталне заједнице. Румуни неопротестанти у насељима Баната имају помоћ пастора из Румуније, посебно из оближњих прекограничних насеља, који врло често посећују заједнице, а проповедници одржавају тематске евангелизације на румунском језику. Оне су отворене за ширу заједницу, са циљем да се на тај начин укључе нови верници.

Неопротестанти наглашавају наднационални карактер својих заједница и универзалност свог учења. Тако, етничка припадност верника није важна за приступање заједници. "Код нас назарена не постоје Румуни, Словаци, Мађаpu, него смо сви ми само то, назарени (Н, Банатско Ново Село); “Ми не кажемо да смо ми румунска црква, ирква може бити само Христова. Код нас се уздиже нација, а не оно што ми проповедамо, само јеванђеље (Б, Вршац); "Не постоји разлика. Говорим од самих Рома који су највише дискриминисани у нашем друштву. Нема, не постоји та социјална и етничка разлика" (П, Вршац).

У Војводини, неопротестантске заједнице су веома етнички мешовите, а богослужења се одвијају на више језика. Језик је једини дистинктивни елемент који разликује припаднике различитих етничких заједница, окупљених око религијске припадности. Наднационални карактер, али и етнички мешовита структура заједница, довеле су до већег степена мешовитих бракова, будући да се брак може склопити само унутар заједнице, или са неким ко би приступио заједници.

Разговор о религијски другом, односно о припаднику друге верске заједнице, која је истовремено и мањинска, отвара и питање негативне маркираности и одбацивања од стране већинске заједнице. Дистанца коју припадници већинске конфесије имају према другим верским заједницама може представљати и важан елеменат у формирању и јачању религијског идентитета тих заједница. Постојање секти и деноминација, како истиче Милан Вукомановић, представља феномен карактеристичан за плуралистичка друштва (Вукомановић 2001: 122). Међутим, оно што је у неким деловима Европе „прототип“ хришћанске цркве (православна или католичка), у другим културним срединама може деловати необично и далеко. Управо је вредносни конфликт са доминантном културом један од начина разликовања секте од цркве. Вукомановић наводи и пример Амиша као верске групе која је развила алтернативну вредносну орјентацију која не води акултурацији.

На основу резултата квалитативног истраживања у којем је једно од питања био однос према другима, највећа дистанца постоји између припадника Румунске православне цркве и назаренске заједнице, будући да се назарени перципирају и као „најзатворенији“ и ,радикалнији“ у односу на друге неопротестанте. Сличан однос према назаренима имају и припадници других неопротестантских заједница баптисти, адвентисти, пентекосталци (Ђурић Миловановић 2015: 259). Управо је сложен однос шире заједнице условљен двоструко 
мањинским положајем Румуна неопротестаната, који представљају мањину у мањини. Етнолог Гордана Благојевић се у студији о Кинезима баптистима такође ослања на концепт двоструких мањина, будући да и ова заједница представљају двоструку мањину, како у земљи пријема (религијску и етничку), као и на већинску вероисповест својих сународника (Благојевић 2011: 97). Концепт двоструке мањине, применљив је и на сличне примере које можемо наћи и у другим етничким и религијским заједницама, и он указује на чињеницу да границе етничког и религијског идентитета нису унапред дефинисане, предодређене и непроменљиве, као и да су идентитети плурални. Бауман сматра да су етницитет и религија два елемента која могу уобличавати и мањинске групе и да оба имају кључну улогу у изградњи заједничких друштвених идентитета и колективних представа у себи (Bauman 1999). Флуидност и комплексност етничког и религијског идентитета у савременом друштву, представља изазов будући да није могуће обухватити и укалупити „пожељне“ облике верског или етничког плурализма. То се посебно примећује у јавним дискурсима о мултиетницитету или мултиконфесионалности, где само оне заједнице које се сматрају „традиционалним“ и друштвено прихватљивим, постају елемент који обогаћује. Стога је у већини заједница које сам истраживала, присутна и својеврсна „верска мимикрија“, како у изјашњавању верника да припадају неопротестантским заједницама, тако и у молитвеним домовима у којима се окупљају. Молитвени домови су најчешће неупадљиве сеоске куће, са веома дискретним натписима на којима стоји назив заједнице и сатница богослужења.

\section{Завршна разматрања}

Указујући на плурализам идентитета које појединац данас може имати, Андреа Семприни (2004: 9) сматра да је ,једно од великих питања које је мултикултурализам поставио, питање различитости? Које место јој доделити унутар једног друштвеног система?“ Румуни неопротестанти представљају мањину мањине или двоструку мањину будући да припадају малој верској заједници, али су истовремено и припадници етничке мањине у Србији. Као такав, овај тип мањинског идентитета не уклапа се у традиционалне оквире мањинских идентитета који се посматрају као хомогене категорије и где се инсистира на јасно дефинисаним границама припадности одређеној заједници. Иако доминанту вероисповест Румуна представља румунско православље, нову димензију религијског идентитета, ове али и других етничких мањина у Војводини данас, управо дају бројне мале верске заједнице. Иако је однос између етницитета и религиозности комплексан и вишеслојан и врло је тешко изводити коначне закључке, на основу обављеног истраживања може се закључити да је код Румуна неопротестаната изражен снажан осећај припадања одређеној верској заједници: назаренској, баптистичкој, адвентистичкој или пентекосталној. Напуштањем одређеног (доминантног) културолошког система, Румуни неопротестанти се удаљавају од модела „правог Румуна“ у Војводини који је пра- 
вославац, усвајањем другачијих религијских, али и културолошких образаца утемељених у новој верској припадности. Доминантни дискурс у неопротестантским заједницама наглашава непостојање разлика етничкој припадности, социјалном статусу, старосној доби, већ истиче да су верници део заједнице и братства. Дискурси о етничком идентитету усмерени су на уобличавање дискурса о наднационалности, односно једнакости унутар заједница и занемаривања етничких подела, разлика, односно њиховог строгог дефинисања.

Пример Румуна неопротестаната као двоструке мањине, у етничком и религијском смислу, пружа увид у читав мозаик односа између кључних елемената идентитета - етницитета, религије и језика. Залагање за мултикултурализам и толеранцију у јавном дискурсу, нарочито на простору Војводине, понекад изгледа као фаворизовање једног једнострано схваћеног концепта мултикултурализма, који је у већој мери наклоњен етничким/националним мањинама, и који не узима у обзир категорије религијског плурализма и вишеструких идентитета које појединац може имати. Тако припадници малих верских заједница, посебно уколико је реч о двоструким мањинама, остају невидљиви и затворени јер нису препознати као „уобичајени“ тип мањинског идентитета.

\section{Литература}

Aleksov, B. (2006) Religious Dissent between the Modern and the National - Nazarenes in Hungary and Serbia 1850-1914. Wiesbaden: Harrassowitz Verlag.

Aleksov, B. (2010) Nazareni među Srbima: verska trvenja u južnoj Ugarskoj i Srbiji od 1850. do 1914. Beograd: Zavod za udžbenike.

Aleksov, B. (2011) “Jovan Jovanović Zmaj and the Serbian Identity: Between Poetry and History" u: Mishkova, D. (ur.) We, the People. Politics of National Peculiarity in Southeastern Europe. Sofia: Centre for Advanced Studies.

Baumann, G. (1999) The Multicultural Riddle: Rethinking National, Ethnic and Religious Identities. London, New York: Routledge.

Bjelajac, B. (2003) Protestantizam u Srbiji. Prilozi za istoriju reformacijskog nasleđa u Srbiji, deo 1. Beograd: Alfa i omega.

Bjelajac, B. (2010) Protestantizam u Srbiji. Prilozi za istoriju reformacijskog nasleđa u Srbiji, deo 2. Beograd: Soteria.

Blagojević, G. (2011) "Kinezi baptisti: primer dvostruke manjine u Srbiji danas", Glasnik Etnografskog instituta SANU LIX (1): 97-105.

Boneta, Ž. i Banovac, B. (2007) „Religioznost i nacionalizam na hrtvatskoj periferiji veliki scenariji za male zajednice“, Migracijske i etničke teme 23(3): 163-184.

Brubaker, R. (1993) "National Minorities, Nationalizing States and External National Homelands in the New Europe. Notes Toward a Relational Analysis", IHR Reihe Politikwissenschaft, 1-21.

Dawsone, L. L. i Hennebry, J. (1999) "New religions and the internet: recruiting in a new public space". Journal of contemporary religion 14(1): 17-23. 
Djurić Milovanović, A. (2017) “Alternative Religiosity in Communist Yugoslavia: Migration as survival Strategy of the Nazarene community", Open Theology 3: 447457.

Dumont, W. (2003) "Immigrant Religiosity in a Pluri-Ethnic and Pluri-Religious Metropolis: an Initial Impetus for a Typology”, Journal of Contemporary Religion 18(3): 369-384.

Đurić Milovanović, A. (2015) Dvostruke manjine u Srbiji. O posebnostima u religiji $i$ etnicitetu Rumuna u Vojvodini. Beograd: Balkanološki institut SANU.

Gilliat-Ray, S. (2005) "Closed Worlds: (Not) Accessing Deobandi Darul-Ulooms in Britain", Fieldwork in Religion 1(1): 7-33.

Maluckov, M. (1985) Rumuni u Banatu. Novi Sad: Vojvođanski muzej.

Martin, D. (2008) „Porast evangelizma i njegove političke implikacije“. U Desekularizacija sveta, ur. Berger Piter, 51-65. Novi Sad: Mediterran publishing.

Milenković, M. (2008) „Problemi konstitucionalizacije multikulturalizma - pogled iz antropologije“. Etnoantropološki problemi 3(2): 45-57.

Nedeljković, S. (2007) Čast, krv i suze: ogledi iz antropologije etniciteta $i$ nacionalizma. Beograd: Zlatni Zmaj, Odeljenje etnologije i antropologije Filozofskog fakulteta.

Parushev, P. i Pilli, T. (2004) "Protestantism in Eastern Europe to the Present Day", u: McGrath A. i Marks D. C. (ur.) The Blackwell Companion to Protestantism, 155161. Oxford: Blackwell Publishing.

Pavković, N. i Naumović, S. (1996) „Faşancu la Grebenaţ: folklorizam, simboličke strategije i etnički identitet rumunske nacionalne manjine u Banatu“, u: Stanovčić, V. (ur.) Položaj manjina u Saveznoj Republici Jugoslaviji, 697-708. Beograd: SANU, Odeljenje društvenih nauka knj. 19.

Pavković, N., Bandić, D. i Rakić, R. (1978) Male verske zajednice u opštini Pančevo. Beograd: Biblioteka Odeljenja za etnologiju i antropologiju Filozofskog fakulteta u Beogradu.

Pavlásek, M. (2013) “Cross-border Nationalism and Religious Fellowship. A case study of the Czech Protestant community in Serbia”, u: Radović. S. (ur.) Kulturna prožimanja: stanje i perspektive, 195-207. Beograd: Etnografski institut SANU.

Pope, E. A. (1992) "Protestantism in Romania", u: Ramet, S. (ur.) Protestantism and Politics in Eastern Europe and Russia, 157-208. Durham: Duke University Press.

Ramet P. S. (1992) Protestantism and Politics in Eastern Europe and Russia. The Communist and Post-Communist Eras. Durham: Duke University Press.

Romelić, J., Nagy I. i Bjeljac, Ž. (2010) "Degradation Process in Rural Borderline Settlements in the Region of Vršac Mountains", Zbornik radova Geografskog instituta ,Jovan Cvijić” SANU. Beograd: Geografski institut SANU, 1-15.

Semprini, A. (2004) Multikulturalizam. Beograd: Clio.

Sikimić, B. (2008) „Etnolingvistički terenski rad: konceptualizacija rizika“, Zbornik radova Etnografskog instituta $S A N U, 81-93$.

Sikimić, B. (2013). „Români din Banatul sârbesc între est şi vest”, Anuar 2012. Zrenianin: Institutul de Cultură a românilor din Voivodina, 134-158.

Sinani, D. (2010) „Dawn by Law. Alternativni religijski koncepti i srpski Zakon o crkvama 
i verskim zajednicama“, Antropologija 3(10):121-132.

Stojković, B., Radojković, M. (2003) Informaciono-komunikacioni sistemi. Beograd: Clio.

Vukomanović, M. (2001). Sveto i mnoštvo: izazovi religijskog pluralizma. Beograd: Čigoja.

\title{
Интернет извори
}

Попис становништва, домаћинстава и станова 2011. у Републици Србији. Републички завод за статистику. Београд 2012. Доступан на: https://pod2.stat.gov.rs/ ObjavljenePublikacije/Popis2011/Nacionalna\%20pripadnost-Ethnicity.pdf

Закон о заштити права националних мањина. Сл. лист СРJ, бр. 11/2002, Сл. лист СЦГ, бр. 1/2003 - Уставна повеља и Сл. гласник РС, бр. 72/2009 - др. закон, 97/2013 - одлука УС и 47/2018. Доступан на: https://www.paragraf.rs/propisi/ zakon_o_zastiti_prava_i_sloboda_nacionalnih_manjina.html

Закон о црквама и верским заједницама. Сл. гласник $P C$, бр. 36/2006. Доступан на: https://www.paragraf.rs/propisi/zakon_o_crkvama_i_verskim_zajednicama.html

\section{Aleksandra Đurić Milovanović}

\section{HIDDEN IDENTITIES OF ROMANIAN NEO-PROTESTANT COMMUNITIES IN VOJVODINA}

\begin{abstract}
In Serbia, minority religious communities are usually seen from one type of minority identity - ethnic one. Thus, the lack of research still exists when it comes to the religious identity of minority communities and the complex relationship between ethnic and religious identity. Based on several years of ethnographic fieldwork among neo-Protestant Romanians in Vojvodina, in this paper I am analyzing ethnic and religious identity of minority communities as double minorities. Starting from the hypothesis that boundaries of ethnic and religious identity are not predefined and static, I analyze narratives collected in four neo-Protestant communities. The case study of Romanian neo-Protestants in this paper indicates what is the role of conversion in ethnic and religious minority communities, but also how religious identity becomes more important in supra-national religious groups.
\end{abstract}

Keywords: minorities in Serbia, Romanians in Vojvodina, religious identity, double minorities, neo-Protestants 